\title{
PENGEMBANGAN PERANGKAT PEMBELAJARAN PADA MATAKULIAH STATISTIKA DASAR DENGAN METODE PROBLEM BASED LEARNING
}

\author{
Ikan Krisdiana \\ Program Studi Pendidikan Matematika, FPMIPA, IKIP PGRI MADIUN \\ Email :ika.mathedu@ikippgrimadiun.ac.id
}

\begin{abstract}
Tujuan dalam penelitian ini adalah pengembangan perangkat pembelajaran pada matakuliah statistika dasar dengan metode Problem Based Learning. Penelitian ini merupakan penelitian pengembangan yang mengikuti mekanisme dan rancangan pengembangan bahan ajar (Fenrich, 1997). Adapun langkah-langkah pengembangan bahan ajar tersebut meliputi fase analysis (analisis), planning (perencanaan), design (perancangan), development (pengembangan), implementation (implementasi), evaluation and revision (evaluasi dan revisi). Tahap awal penelitian pada tahun pertama adalah menyusun instrumen untuk investigasi, melakukan analisis (analysis), membuat perencanaan (planning), merancang (design), development (pengembangan), dan implementation (implementasi). Pada penelitian ini perangkat pembelajaran yang telah dirancang meliputi: Silabus, SAP dan Buku Ajar Statistika Dasar. Hasil penelitian ini adalah perangkat pembelajaran statistika dasar yang meliputi silabus, SAP, dan Bahan Ajar. Dari hasil perangkat pembelajaran tersebut menunjukkan bahwa perangkat pembelajaran yang telah dikembangkan dapat dikatakan sebagai perangkat pembelajaran yang baik karena memenuhi kriteria kevalidan, kepraktisan, dan keefektifan.
\end{abstract}

Keyword: Perangkat Pembelajaran, Statistika Dasar, Problem Based Learning

\section{PENDAHULUAN}

Statistika merupakan matakuliah wajib yang harus ditempuh oleh mahasiswa program studi pendidikan matematika di Fakultas Pendidikan Matematika dan Ilmu pengetahuan Alam IKIP PGRI Madiun. Dalam matakuliah statistika khususnya statistika dasar diharapakan mahasiswa mampu memahami semua materi dimana materi tersebut berkaitan dengan matapelajaran matematika di SMA, MA dan SMK. Walaupun materi tersebut mudah tetapi mahasiswa masih belum begitu tertarik untuk mengikuti pembelajaran. Hal ini dijelaskan Shi (2009:7) bahwa salah satu penyebab peserta didik kurang tertarik terhadap statistika dikarenakan statistika masih diajarkan secara teoritis dan kurang terhubung dengan dunia nyata. Dengan demikian mahasiswa tidak mengetahui aplikasi pada tiap-tiap materi tersebut. Penyampaian perkuliahan statistika masih menggunakan metode ceramah atau model transfer pengetahuan masih tetap menjadi metode andalan (Leibman, 2010: 15). Sehingga menyebabkan motivasi mahasiswa untuk mengikuti perkuliahan bahkan mempelajari statistika menjadi menurun. Menurut Leibman (2010: 4) bahwa mempelajari suatu pengetahuan seharusnya dihubungkan dengan dunia nyata serta dijelaskan abagaimana aplikasinya. Akibatnya prestasi mahasiswa pada matakuliah statistika dasar terutama pada kemampuan pemecahan masalah menjadi rendah.

Perkuliahan dikatakan berhasil jika perangkat dalam pembelajaran dipersiapkan semaksimal mungkin sebelum perkuliahan berlangsung. Dalam hal ini perangkat pembelajarannya meliputi silabus, sap, lembar kerja mahasiswa, bahan ajar/modul. Tanpa adanya perencaan perangkat pembelajaran perkuliahan tidak akan bejalan secara lancar dan hasilnya pasti tidak akan memuaskan. Dalam penyusunan perangkat pembelajaran terus dikembangkan inovasi-inovasi yang baru sehingga pembelajaran yang diharapkan dapat menghasilkan sesuatu yang bermakna sesuai yang diinginkan oleh mahasiswa dan dosen.

Metode pemecahan masalah yang sering disebut dengan problem based learning diawali 


\section{JEMS (Jurnal Edukasi Matematika dan Sains)}

Tersedia online di: http://e-journal.ikippgrimadiun.ac.id/index.php/JEMS

Volume 4, Nomor 1, Maret 2016, hal 61- 65

dengan pemberian permasalahan didunia nyata yang berfungsi sebagai dasar mahasiswa untuk melakukan investigasi. Menurut pernyatan Savery dan Dufffy (dalam Savery 2006: 13) bahwa motivasi peserta didik meningkat saat diberi tanggung jawab untuk menyelesaikan sebuah permasalahan. Menurut Arends (2008: 43) Problem Based Learning dirancang untuk membantu peserta didik mengembangkan keterampilan berfikir, meyelesaikan masalah. Metode pemecahan masalah atau problem based learning mengajarakan kepada mahasiswa untuk bekerja keras menyelesaikan masalah dalam hal ini berkaitan dengan matakuliah statistika dasar, mengajarkan teliti dalam memahami permasalahan.

Dengan adanya penerapan perangkat pembelajaran dengan menggunakan metode Problem Based Learning dapat meningkatkan motivasi belajar mahasiswa, meningkatkan prestasi belajar khususnya matakuliah statistika dasar dan juga meningkatkan kemampuan pemecahan masalah.

Dari uraian diatas, permasalahan yang akan dikaji pada penelitian ini adalah (1) bagaiaman pengembangan perangkat pembelajaran pada matakuliah satatistika dasar dengan metode Problem Based Learning (2) Apakah pembelajaran dengan pengembangan perangkat pembelajaran dengan metode problem based leraning dapat meningkatkan prestasi belajar mahasiswa.

\section{METODE PENELITIAN}

Penelitian ini termasuk penelitian pengembangan. Pengembangan perangkat pembelajaran di penelitian ini mengacu pada model pengembangan Plomp yang terdiri dari lima fase yaitu investigasi awal (prellimenary investigasi), fase desain (design), fase realisasi (realization/construction), fase tes, evaluasi dan revisi (tes, evalution, dan revision), dan implementasi (implementation).
Populasi dalam penelitian ini adalah semua mahasiswa program studi pendidikan matematika FPMIPA IKIP PGRI Madiun semester 3 yang terdiri dari 3 kelas yang berjumlah 95 mahasiswa Tahun Akademik 2015/2016. Subyek penelitian dipilih satu kelas dalam 3 kelas dengan menggunakan teknik random sampling.

\section{HASIL DAN PEMBAHASAN}

Pelaksanaan kegiatan penelitian ini diawali persiapan antara lain: (1) Membagi tim untuk mencari/membeli literatur sebagai bahan acuan pengembangan perangkat pembelajaran (Bahan Ajar Statistika, SAP dan Silabus) (2) Membuat jadwal pelaksanaan penelitian pada tahap I, (3) Membagi tim dalam pembuatan draft (bahan ajar, silabus, dan SAP ).

Setelah persiapan, berikut diuraikan tahapan pengembangan perangkat pembelajaran berdasarkan Fenrich (1997) yang meliputi empat fase, yaitu: (1) fase analisis meliputi analisis silabus dan SAP, (2) fase perencanaan meliputi perencanaan lembar validasi silabus, SAP, Bahan Ajar, (3) fase desain meliputi Silabus, SAP, dan Bahan Ajar (4) fase pengembangan, dan (5) fase impelementasi. Pada fase pengembangan telaah dan penilaian kelayakan komponen Bahan ajar yang dikembangkan meliputi Silabus, SAP dan Buku Ajar Statistika Dasar oleh validator internl. Validator internal adalah dosen Program Studi Pendidikan Matematika IKIP PGRI Madiun yaitu: (1) Drs. Sanusi, M.Pd, (2) Wasilatul Murtafi'ah, M.Pd. Hasil Validasi Sebagai berikut:

\section{Hasil Validasi SAP}

Hasil validasi atau penilaian oleh kedua validator internal dan eksterna terhadap satuan acara perkuliahan (SAP) yang telah dikembangkan oleh tim peneliti disajikan sebagai berikut:

Tabel 1. Hasil Validasi SAP

\begin{tabular}{|c|c|c|c|c|}
\hline \multirow[t]{2}{*}{ No. AspekPenilaian } & \multicolumn{4}{|c|}{$\begin{array}{l}\text { Banyak Validator } \\
\text { yang Memberinilai }\end{array}$} \\
\hline & 1 & 2 & 3 & 4 \\
\hline \multicolumn{5}{|l|}{ TujuanPembelajaran } \\
\hline 1 Menuliskan Kompetensi Dasar (KD) & 0 & 0 & 2 & 0 \\
\hline 2 Ketepatan penjabaran dari KD ke Indikator & 0 & 0 & 0 & 2 \\
\hline
\end{tabular}


JEMS (Jurnal Edukasi Matematika dan Sains)

Tersedia online di: http://e-journal.ikippgrimadiun.ac.id/index.php/JEMS

Volume 4, Nomor 1, Maret 2016, hal

\begin{tabular}{llllll}
\hline \multicolumn{2}{l}{ FasePembelajaran } & & & & \\
\hline 1 & Metode yang dipilih sesuai dengan tujuan pembelajaran & 0 & 0 & 2 & 0 \\
\hline 2 & Fase-fase dari metode pembelajaran ditulis lengkap dalam SAP & 0 & 0 & 1 & 1 \\
\hline 3 & $\begin{array}{l}\text { Fase-fase dalam sintaks pembelajaran memuat urutan kegiatan } \\
\text { pembelajaran yang logis }\end{array}$ & 0 & 0 & 1 & 1 \\
\hline 4 & $\begin{array}{l}\text { Fase-fase dalam sintaks pembelajaran memuat denganjelas peran } \\
\text { dosen }\end{array}$ & 0 & 0 & 2 & 0 \\
\hline 5 & Fase-fase dalam sintaks pembelajaran dapat dilaksanakan dosen & 0 & 0 & 0 & 2 \\
\hline Waktu & & & & \\
\hline 1 & $\begin{array}{l}\text { Pembagian waktu setiap kegiatan/fase dinyatakan dengan jelas } \\
2\end{array}$ & 0 & 0 & 2 & 0 \\
\hline PerangkatPembelajaran & 0 & 0 & 0 & 2 \\
\hline 1 & $\begin{array}{l}\text { Bahan ajar mahasiswa menunjang ketercapaian tujuan } \\
\text { pembelajaran }\end{array}$ & 0 & 0 & 1 & 1 \\
\hline 2 & Media menunjang ketercapaian tujuan pembelajaran & 0 & 0 & 0 & 2 \\
\hline 3 & Lembar penilaian sesuai dengan Indikator & 0 & 0 & 2 & 0 \\
\hline 4 & $\begin{array}{l}\text { Bahan ajar, media, dan tes hasil belajar diskenariokan } \\
\text { penggunaanya dalam SAP }\end{array}$ & 0 & 0 & 2 & 0 \\
\hline MetodeSajian & & & & \\
\hline 1 & Sebelum menyajikan konsep baru, sajian dikaitkan dengan konsep \\
& yang telah dimiliki mahasiswa & 0 & 0 & 1 & 1 \\
\hline 2 & Memberikan kesempatan bertanya kepada mahasiswa & 0 & 0 & 1 & 1 \\
\hline 3 & Dosen mengecek pemahaman mahasiswa & 0 & 0 & 1 & 1 \\
\hline 4 & Memberi kemudahan terlaksananya KBM yang inovatif & 0 & 0 & 1 & 1 \\
\hline Bahasa & & & & \\
\hline 1 & Menggunakan kaidah Bahasa Indonesia yang baik dan benar & 0 & 0 & 0 & 2 \\
\hline 2 & Ketepatan struktur kalimat & 0 & 0 & 1 & 1 \\
\hline 3 & Kemutakhiran daftar pustaka & 0 & 0 & 1 & 1 \\
\hline & & & & & \\
\hline
\end{tabular}

Keterangan:

1 : berarti "sangat tidak baik" 3 : berarti "baik"

2 : berarti "tidak baik" 4 : berarti "sangat baik"

Dari Hasil telaah kedua validator internal memberikan penilaian $3 \mathrm{ke}$ atas. Hal tersebut menunjukkan bahwa komponen-komponen dalam silabus dan SAP mendapatkan penilaian baik dan sangat baik. Validator juga memberikan saran agar revisi dilakukan pada beberapa tulisan yang salah. Kesimpulan berdasarkan hasil validasi silabus dan SAP yang telah dikembangkan oleh tim peneliti layak digunakan dengan sedikit revisi.

\section{Hasil Validasi Buku Ajar}

Hasil validasi atau penilaian oleh kedua validator internal terhadap Buku Ajar yang telah dikembangkan oleh tim peneliti disajikan sebagai berikut :

Tabel 2 Hasil Validasi Buku Ajar

\begin{tabular}{|c|c|c|c|c|c|}
\hline \multirow[t]{2}{*}{ No. } & \multirow[t]{2}{*}{ AspekPenilaian } & \multicolumn{4}{|c|}{$\begin{array}{l}\text { Banyak Validator } \\
\text { yang MemberiNila }\end{array}$} \\
\hline & & 1 & 2 & 3 & 4 \\
\hline \multicolumn{6}{|c|}{ Format } \\
\hline 1 & Kejelasanpembagianmateri & 0 & 0 & 1 & 1 \\
\hline 2 & Memilikidayatarik & 0 & 0 & 2 & 0 \\
\hline 3 & Sistempenomoranjelas & 0 & 0 & 1 & 1 \\
\hline 4 & Kesesuaianantarateksdanilustrasi & 0 & 0 & 0 & 2 \\
\hline 5 & Pengaturanruang/tataletak & 0 & 0 & 2 & 0 \\
\hline 6 & Jenisdanukuranhurufsesuai & 0 & 0 & 0 & 2 \\
\hline
\end{tabular}


JEMS (Jurnal Edukasi Matematika dan Sains)

Tersedia online di: http://e-journal.ikippgrimadiun.ac.id/index.php/JEMS

Volume 4, Nomor 1, Maret 2016, hal 61- 65

\begin{tabular}{|c|c|c|c|c|c|}
\hline \multicolumn{6}{|c|}{ Bahasa } \\
\hline 1 & Kebenaran tata bahasa & 0 & 0 & 0 & 2 \\
\hline 2 & Kesesuaian kalimat dengan taraf berpikir dan kemampuan mahasiswa & 0 & 0 & 1 & 1 \\
\hline 3 & Kesederhanaan struktur kalimat & 0 & 0 & 2 & 0 \\
\hline 4 & Mendorong minat baca & 0 & 0 & 1 & 1 \\
\hline 5 & Kalimat tidak mengandung arti ganda & 0 & 0 & 2 & 0 \\
\hline 6 & Sifat komunikatif bahasa yang digunakan & 0 & 0 & 1 & 1 \\
\hline \multicolumn{6}{|c|}{ Ilustrasi } \\
\hline 1 & Dukungan ilustrasi untuk memperjelas konsep & 0 & 0 & 1 & 1 \\
\hline 2 & Memberi rangsangan secara visual & 0 & 0 & 1 & 1 \\
\hline 3 & Memiliki tampilan yang jelas & 0 & 0 & 2 & 0 \\
\hline 4 & Mudah dipahami & 0 & 0 & 1 & 1 \\
\hline \multicolumn{6}{|c|}{ 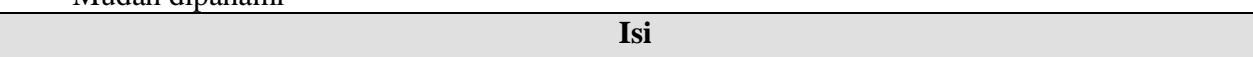 } \\
\hline 1 & Kebenaran isi /materi & 0 & 0 & 2 & 0 \\
\hline 2 & Merupakan materi yang esensial & 0 & 0 & 1 & 1 \\
\hline 3 & Dikelompokkan dalam bagian-bagian yang logis & 0 & 0 & 0 & 2 \\
\hline 5 & Kesesuaian tugas dengan urutan materi & 0 & 0 & 0 & 2 \\
\hline 6 & $\begin{array}{l}\text { Peranannya untuk mendorong mahasiswa dalam memahami } \\
\text { konsep/prosedur }\end{array}$ & 0 & 0 & 1 & 1 \\
\hline 7 & Kelayakan sebagai bahan ajar & 0 & 0 & 2 & 0 \\
\hline & $\begin{array}{l}\text { tidak baik" } 3 \text { : berarti "baik" } \\
\text { aik" } \\
4: \text { berarti "sangat baik" }\end{array}$ & & & & \\
\hline
\end{tabular}

Sedangkan pada buku ajar menunjukkan kedua validator memberikan penilaian $3 \mathrm{ke}$ atas. Hal tersebut menunjukkan bahwa komponenkomponen dalam Buku Ajar mendapatkan penilaian baik dan sangat baik. Validator juga memberikan saran/masukan terhadap draft 1 Buku Ajar. Revisi berdasarkan saran/masukan dari para validator dilakukan di beberapa bagian yang salah ketik maupun salah konsep. Buku Ajar yang telah dirancang oleh tim peneliti dapat digunakan dengan sedikit revisi. Pada Fase implementasi yang dilakukan adalah penerapan Silabus, SAP dan Bahan Ajar. Dari hasil implementasi menunjukkan nilai Akhir Mahasiswa pada matakuliah Statistika Dasar adalah $12,5 \%$ mendapat nilai A, $75 \%$ mendapatkan nilai $\mathrm{B}, 12,5 \%$ mendapatkan nilai $\mathrm{C}$ dengan menerapkan bahan ajar yang telah dikembangkan oleh peneliti.

\section{KESIMPULAN}

Pada kegiatan penelitian ini telah dirancang prototipe perangkat pembelajaran pada mata kuliah Statistika Dasar yang meliputi Silabus, SAP, danBuku Ajar pada matakuliah Statistika Dasar. Dari hasil perangkat pembelajaran tersebut menunjukkan bahwa perangkat pembelajaran yang telah dikembangkan dapat dikatakan sebagai perangkat pembelajaran yang baik karena memenuhi kriteria kevalidan, kepraktisan, dan keefektifan.

\section{DAFTAR PUSTAKA}

Arends, Richard I. 2008. Learning To Teach. Yogyakarta: Pustaka Belajar

Fenrich, P., 1997. Practical Guidelines for Creating Instructional Multimedia Applications.Fort Worth: The Dryden Press Harcourt Brace College Publishers.

Leibman, Integrating Real-Life Data analysis in Teaching Descriptive Statistic: A Constructive Approach. Jornal of Statistic Education. (1). (www. Amstat.org/publishcations/jse/v18n1/ libman 2010), diaksespadatanggal 14 September 2015

Plomp. T. (2010). Generic Model for Educational Design (Problem, Analysis, Design, Implementation, 
JEMS (Jurnal Edukasi Matematika dan Sains)

Tersedia online di: http://e-journal.ikippgrimadiun.ac.id/index.php/JEMS

Volume 4, Nomor 1, Maret 2016, hal

Evaluation). Enschede: University of

Twente

Savery, John R. 2006. Overview of Problem

Based Learning: Definitions and

Distinction. The Interdisplynary

Journal of Problem Based Learning.

Volume 1, no. 1 (Spring 2006). 9-20

Shi, Ning-zhon. 2009. Understanding Statistic and statistic Education: A Chinese

Perspektive. Journal of

StatisticEducation. 17 (3), (1-8). 